Article

\title{
The Transformative Potential of Active Citizenship: Understanding Changes in Local Governance Practices
}

\author{
Thomas J.M. Mattijssen ${ }^{1, *}$, Arjen A.E. Buijs ${ }^{2,3}{ }^{(}$, Birgit H.M. Elands ${ }^{2}{ }^{(}$, Bas J.M. Arts ${ }^{2,4}$, \\ Rosalie I. van Dam ${ }^{3}$ and Josine L.M. Donders ${ }^{3}$ \\ 1 Wageningen Economic Research, Wageningen University Research, Prinses Beatrixlaan 582, \\ 2595 BM Den Haag, The Netherlands \\ 2 Forest and Nature Conservation Policy Group, Wageningen University Research, Droevendaalsesteeg 3-3 A, \\ 6708 PB Wageningen, The Netherlands; arjen.buijs@wur.nl (A.A.E.B.); birgit.elands@wur.nl (B.H.M.E.); \\ bas.arts@wur.nl (B.J.M.A.) \\ 3 Wageningen Environmental Research, Wageningen University Research, Droevendaalsesteeg 3-3 A, \\ 6708 PB Wageningen, The Netherlands; rosalie.vandam@wur.nl (R.I.v.D.); josine.donders@wur.nl (J.L.M.D.) \\ 4 PBL Netherlands Environmental Assessment Agency, P.O. Box 30314, 2500 GH The Hague, The Netherlands \\ * Correspondence: thomas.mattijssen@wur.nl
}

Received: 14 April 2019; Accepted: 12 October 2019; Published: 18 October 2019

check for updates

\begin{abstract}
This paper focuses on understanding the transformative potential of active citizenship in green space governance. Through an in-depth case study, we show how citizens promoted the redevelopment of a brownfield into a green space, but eventually also contributed towards a broader co-creative shift in local governance. In this process, we highlight how a shift in citizens' activities from contestation towards collaboration led to the uptake of citizen-driven discourses and activities in spatial planning. The social connectivity between governance practices is of key importance in this transformation-successful governance practices that involve active citizens can inspire others. Even so, transformation is often a slow and path-dependent process which also depends on an enabling policy environment. Cooperating with authorities provides citizens with power, but also requires alignment with official rules. Creating and maintaining effective partnerships will remain a challenge for citizens and policymakers that strive for societal transformations.
\end{abstract}

Keywords: active citizenship; citizens; transformation; co-governance; re-naturing cities; practice theory; policy arrangement approach; urban socio-ecological systems; green spaces

\section{Introduction}

In late modern society, the term active citizenship has risen to prominence to describe the role of citizens in the public domain [1]. In the current literature, these citizens are considered as capable, self-organizing agents who actively pursue their own interests in the public domain [2,3]. Many people are concerned about the world in which they live and want to contribute towards the realization of a wide range of public values [3]. Research highlights many examples in which citizens successfully contribute to important public benefits across various policy domains [1]. When citizens feel challenged and motivated to address their concerns, and when they are sufficiently equipped and skilled to do so, they could be expected to act in the public domain [4] - with or without the involvement of authorities.

In this article, we specifically focus on the role of citizens in the governance of urban green space-a field in which citizens have become an increasingly important actor [5,6]. In many cities, encroachment and ongoing urban sprawl combined with declining maintenance budgets have put pressure on the quantity and quality of public green spaces. While local authorities are often the 
main governors of these spaces, scarcity of public resources for green space management and policy ambitions to empower citizens have spurred an interest in the role of active citizenship [7,8]. This is supported by the emergence of increasing numbers of bottom-up initiatives by citizens, who do not wait for authorities to act but employ their own activities in the public green domain [2,9].

Across cities, it has been shown how citizens engage in a wide range of governance practices for greening urban spaces or protesting against urban development [10,11]. Many citizens are concerned about the social and environmental benefits of urban green and about threats to green areas, which motivates them to become active [12]. Independently or in cooperation with authorities and other actors, these citizens have the potential to realize a wide range of environmental and social benefits [13]. Research in the domain of urban green space has shown how active citizenship has contributed to public health benefits, urban biodiversity, environmental education, urban greening, recreation, and social cohesion [10,13-15]. With this, active citizens can promote the benefits that are offered by urban green infrastructure [8].

In their literature review, Wolfram and Frantzeskaki [16] point out that many studies link urban sustainability challenges with social innovation, grassroots movements, and new forms of governance. Yet, while there is currently much interest in active citizenship in governance, practices in which government authorities play a dominant role continue to exist as well $[17,18]$. In contemporary society, therefore, many different governance practices coexist. Such governance systems, in which different actors, including government authorities, citizens, NGOs, communities, and businesses seek to accomplish their objectives, are polycentric, and increasingly complex [19]. When citizens become active, they enter a complex and heterogeneous institutional context $[8,20]$ and often need to deal with other stakeholders in order to pursue their own objectives.

\section{The Transformation of Local Governance Systems}

Active citizenship in the city does not only impact the environment but also raises questions on how cities should be governed [21]. Many citizens become active not only to realize direct environmental or societal values and benefits, but also to transform existing governance practices, for example by demanding more democracy, urban greening, or a deeper transition towards sustainability $[1,22,23]$. In this context, Isin [24] distinguishes between 'active' and 'activist' citizenship to highlight how 'activist' citizens also aim for more fundamental societal change. Also, in the city, active citizenship has been linked to activism, as many citizens desire to promote fundamental changes in the urban environment [21]. With this, citizens regularly aim to challenge existing governance institutions, which can put them at odds with authorities and raise conflicts of interest or power struggles [25].

In this context, it is an important question whether active citizenship can contribute not only to direct environmental or societal values and benefits but also to a transformation of institutions in governance. It has been doubted whether such 'activist' goals of active citizenship are achievable. Critical scholars point out that active citizenship often remains small-scale [26] or claim that the involvement of active citizens in governance merely reproduces existing power relations $[18,23]$. Indeed, many practices that involve active citizenship have not shown an ability to affect existing governance practices significantly, and through those, societal domains as a whole [27].

Critical perspectives show how governments also fail to find proper mechanisms to connect to active citizens [28]. Citizens often experience a lack of support from authorities or are even constrained by existing policies, which prevents them from realizing substantive outcomes [3,27]. Research has shown that citizens often need to engage with authorities and align with legal frameworks in order to be successful in the public domain $[2,6,15]$. In this respect, 'growing' for citizens often means 'adapting' [20]. Weak connections with formal governance institutions generally preclude upscaling of citizens' practices and their outcomes [29].

These critical studies paint a somewhat bleak perspective for active citizens that aim for a change in governance or for societal transitions. However, others do suggest that active citizenship can be considered as a seedbed for more systemic changes in the green city and promote 
institutional as well as environmental change [21,30]. In scientific fields of study such as social innovation, new communitarianism, new social movements, and transition studies, citizens are seen as knowledgeable agents capable of influencing politics and building environmental and social resilience.

In this paper, we discuss the transformative potential of active citizenship in green space governance. Following Wagenaar et al. [22], we understand this as the potential of active citizenship for realizing transformation in the relationship between the state, market, and civil society in the design and delivery of locally valued products and services. We aim to contribute towards an understanding of the role of active citizenship in the development and transformation of governance practices. We focus on transformations in the relationship between citizens and authorities and the delivery of green space as a local service. In the domain of urban green space, this insight is important for understanding if and how citizens can transform existing governance practices, realize substantive outcomes, and instigate democratic renewal.

We address the above debates with a case study in the Dutch city of Amersfoort. The research question which we address in this paper is the following:

What is the transformative potential of active citizenship in urban green space governance?

\section{Theory}

\subsection{A Practice-Based Approach}

The literature increasingly emphasizes the relevance of local practices in governance, including practices initiated by citizens $[9,27]$. In this paper, we employ a practice-based approach [31] to study the transformative potential of active citizenship. Practice theory understands social reality as human activity [32]. However, practice theory does not focus solely on the actions of individual human beings, nor on the influence of external structures or institutions on human behavior [33]. Rather, it takes a 'middle position' and argues that social reality should be understood through the empirical analysis of 'social practices,' of which both agents and structures are a part.

Practice scholars argue that social practices should be seen and assessed as a whole [34,35]. The elements that are used in or are part of a practice gain their social meaning through the practice as a whole. So, while a gardening tool is a material resource in itself, it only gains its social meaning as part of gardening practices. Similarly, language and discourse gain their social meaning through their embeddedness in daily practices. Practices that share similar elements (e.g., teaching practices, nature conservation practices) are seen as bundles [32].

Practices are teleoaffective-they have an orientation towards an end, a telos [36]. This telos could be seen as a future dimension that makes people engage in a social practice [37]. Affectivity is what motivates practitioners to engage for the sake of the telos. Affects are 'states of physical arousal, pleasure or displeasure, directed at some definite person, object, or idea' [35]. As highlighted in the idea of teleoaffectivity, active citizens thus engage in governance practices because they want to realize both a certain end-goal and an emotional fulfillment.

The material world is considered to be a crucial and integral component of social practices: nonhuman elements such as natural objects and technological artifacts play a constitutive role in producing social life [38]. In the example given above, the gardening tool co-shapes the gardening practices in which it is used, as it implies certain doings and sayings. Once the tool is replaced by a new one, the gardening practice will also change. Thus, the material world is not merely the substrate of social practices, but it actively shapes how these are performed [39]. Similarly, the activities of citizens in a specific green space are co-produced by the material characteristics of this space. The agency of humans is thus entwined with the material and social situation in which they find themselves. This notion is called 'situated agency' [40]. 


\subsection{Elements of Governance Practices}

Social practice consists of various elements. Several practice scholars have identified different elements. For example, Schatzki [36] distinguishes between understandings, telos/effects, and rules, while Shove, Pantzar, and Watson [34] refer to meanings, competencies, and materiality. For this paper, since it focuses on governance practices, we found inspiration in an established framework for studying governance: the policy arrangement approach or PAA [41]. The PAA helps to understand dynamics in governance processes over time [42] and may aid in identifying and investigating relevant elements of governance practices. The PAA employs four analytical dimensions (see Table 1): discourses, actors, rules, and resources. Here, we understand these dimensions as constitutive elements of a governance practice that are inherently connected with the material and social worlds.

Table 1. Overview of the elements of governance practices.

\begin{tabular}{cc}
\hline Elements & Descriptions \\
\hline Actors & Practitioners involved in governance, being agencies situated in their social and material worlds \\
Discourse & The sayings/narratives of practitioners (indicating their telos/effects) \\
Resources & Material tools and immaterial attributes/competencies of practitioners \\
Rules & Formal and informal guiding principles for 'doing/saying the right thing' (indicating institutions \\
& within practices) \\
\hline
\end{tabular}

\subsection{Transformation in Social Practices}

Social practices are inherently dynamic because they need to be continuously performed in order to exist [34]. Practices may change over time, potentially implying agencies 'doing things otherwise' [43]. Seed for change might stem from the social situation (e.g., new actors entering the governance scene), the material situation (e.g., accelerated deterioration of the green space), or from a change in teleoaffectivity (e.g., new end-goals or the demise of old effects). We speak of change when there is a shift in one or more elements of any number of practices [42]. This change is understood as a transformation when there are shifts on the institutional level (see below).

Although dynamic in principle, social practices often tend to stabilize and reproduce themselves [34]. Elements that are commonly reproduced in practices are considered to be institutionalized [33]. Examples include laws, cultural traditions, and standardized ways of working. Such 'institutionalized elements' often span various social practices. A regulation governing the use of a pesticide is relevant to private gardening, farming, and the maintenance of public green spaces. Hence, these institutionalized elements act as a 'glue' between practices, reinforcing their stability or instigating renewal once they change. A change in institutions can thus be understood as a change of institutionalized elements across practices [44], and it is only through their embedding in concrete practices that institutions continue to exist. In order to study the transformative potential of active citizenship, therefore, we need to understand how citizens, as situated agents, bring about change in discourse, actors, rules, an resources across governance practices.

\section{Material and Methods}

\subsection{Case study Approach and Case Selection}

Below we analyze a single case in Amersfoort, a Dutch city of about 150,000 inhabitants located centrally in the Netherlands. In this case study, we studied the transformation of an old hospital site, the 'Elisabeth site,' into a green park. This transformation was realized through an interactive governance process involving both citizens and policymakers. The case study approach was chosen to study this transformation as it is a holistic approach to the in-depth study of complex social phenomena with a focus on social interactions and multiple viewpoints. A social science case study is a practical real life situation in which conditions cannot be manipulated [45]. Since a social science case study is 
always set in a specific context somewhere on the planet, this approach requires that the researchers are paying close attention to the social and material context in which their study takes place [46].

This case was selected from a large inventory of 264 citizens' initiatives on green space governance that had been conducted in two prior studies $[9,13]$. In both these studies, discussions about the relationship between active citizens and authorities in the context of green space governance had come forward. This was an important motivation to study the scientific literature on this topic and eventually led to the research question presented in this article. The decision to focus on Amersfoort was made because it was identified as an exemplary case, which means that it reflects a strong, positive example of the phenomenon of study [47]—transformation in green space governance through active citizenship. It was specifically selected for its complexity in the involved actors, the interaction between citizens and policymakers, and because we suspected mechanisms of influence between different practices based on the two prior studies mentioned above.

\subsection{Data Collection and Analysis}

We started our fieldwork with an extensive study of relevant documents and websites discussing the Elisabeth site and active citizenship in Amersfoort. A search on the internet and in local media produced 38 sources (policy documents, websites, reports, notes of meetings, surveys) in which one or more of the practices related to redeveloping the Elisabeth site are discussed. An online platform that was used by citizens and policymakers to communicate during the process was also regularly monitored and analyzed. Additional documents were also obtained via a number of local contacts.

In addition to our document analysis, we also conducted a total of 11 personal interviews with nine key respondents (two respondents were interviewed twice, at different times). These interviews were semi-structured-questions for each interview were constructed on the basis of previously collected data and tailored to the specific respondent. Respondents, to whom confidentiality was promised, include 5 citizens and a public official who were directly involved in the co-creation practice concerning the Elisabeth site, a municipal executive councilor, a local member of the municipal council, and a local citizen who is professionally involved with active citizenship and who was directly involved in the process. These respondents were identified in three ways: (1) they were directly involved in the process concerning the transformation of the Elisabeth site, (2) they were found through the document analysis, and (3) they were mentioned by other respondents.

The collected data were qualitatively analyzed and jointly interpreted by four different researchers. The key observations and interesting findings were regularly discussed during the research process and integrated into a jointly written narrative, which was updated several times. During this process, considerable attention was given to identifying different practices, highlighting key elements, studying interactions between practices, and scrutinizing transformations over time. As a final step in the analysis, the main findings were reported back to respondents in a draft report. These respondents were asked to comment on potential inaccuracies and provide additional relevant information to strengthen our analysis. The majority of respondents replied, and their comments were used to improve our analysis in a second round.

\section{Results Part 1: Changing Practices on the Elisabeth Site}

Amersfoort is a rapidly expanding historical city which had been elected as the 'greenest city of the Netherlands' in 2006. While urbanization is ongoing in and around Amersfoort, the city has many parks and is surrounded by a number of green 'nature' areas. In a political and administrative sense, the city is seen by a number of respondents as being a frontrunner when it comes to involving citizens in decision making - although some citizens who have had negative experiences in dealing with the municipality disagree with this. Even so, in quite a number of practices, citizens have cooperated with the municipality in the planning and management of urban green space, as elaborated below. 


\subsection{The Redevelopment of an Old Hospital Site}

The analysis of our case study starts in 1999 when plans for the demolition of the Elisabeth Hospital, and it's replacement by a modern hospital elsewhere in the city emerged. Discussions on new uses for the eight-hectare hospital site quickly arose. Originally, local political parties mostly appeared to be in favor of developing the area for (social) housing in order to accommodate the growth of the city's population and provide (affordable) housing for the cities' population. In response to these visions, a citizen-driven green discourse arose, promoting the development of an ecological corridor from the rural outskirts of the city to the city center.

As Figure 1 shows, the Elisabeth Hospital was located in the center of a green finger running from the rural surroundings to the city center. This area is known as the Heiligenbergerbeekdal, named after a stream that flows through the valley. The Heiligenbergerbeekdal is located in the southeast of Amersfoort and leads from the city borders up to its center.

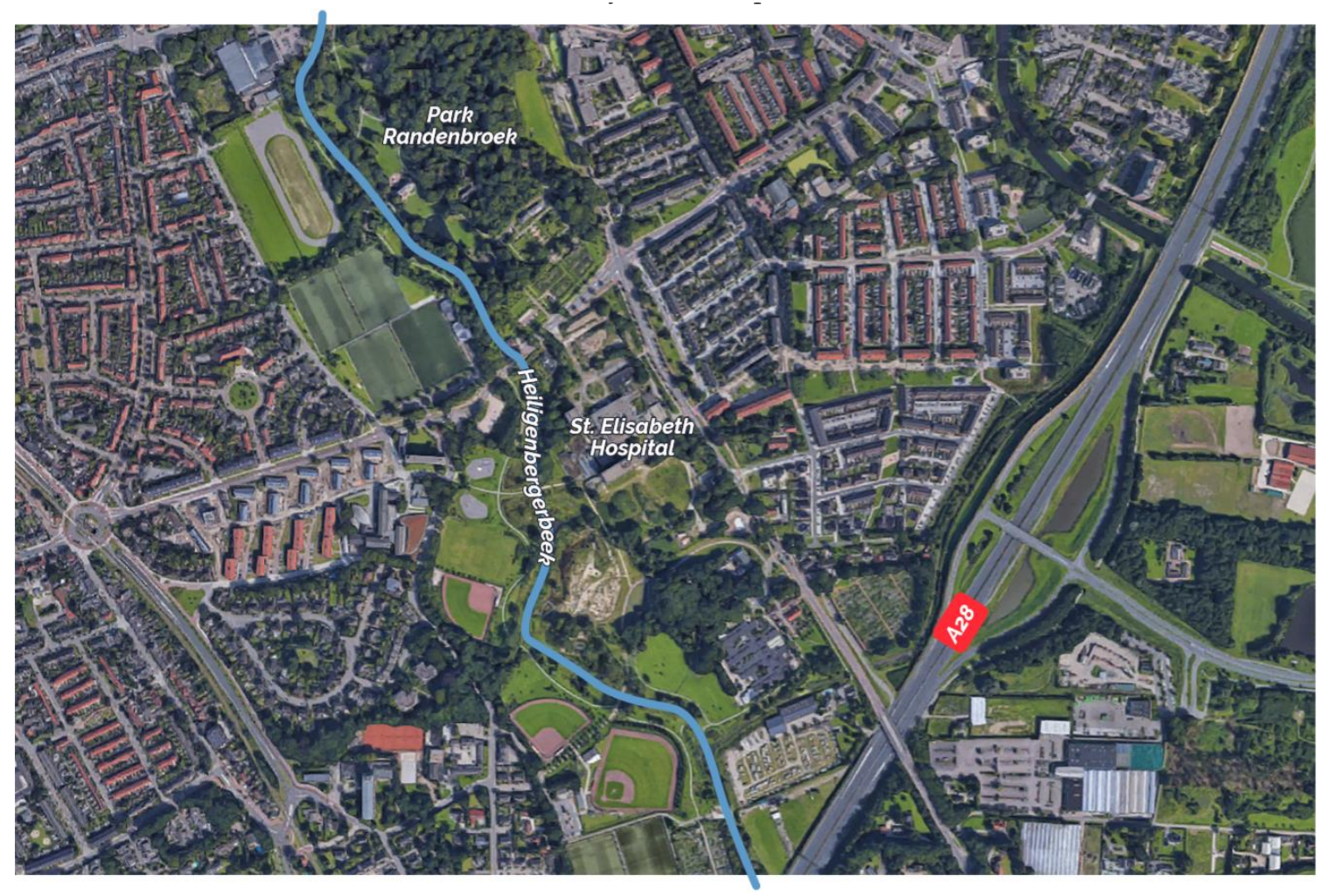

Figure 1. The Heiligenbergerbeekdal. Source: Google Earth. Image edited by the authors.

\subsection{Municipal Participatory Planning Practices}

In the Netherlands, municipal authorities have historically taken a leading role in decision making and implementation of local spatial policies-which was also the case in Amersfoort. From the early 2000s, though, new democratic ideals of participatory governance became part of the municipal planning discourse, and participatory planning methods were gradually adopted, usually still with the municipality taking the lead.

Early participatory planning practices include the redevelopment of Park Randenbroek (2002-2012), a park situated close to the Elisabeth Hospital (Figure 1). Several respondents illustrated how local people were critical of the rather top-down participation processes organized by the municipality for the Park Randenbroek redevelopment. They felt they had little opportunity to provide input and criticized the municipality for being slow and non-transparent and for its poor communication, which led to at least 36 trees being felled by mistake. 
According to both citizens and municipality officials, the above criticism made municipal actors aware of the need for an open debate. This has been widely identified as an important turning point in the adoption of more participatory planning practices. An early example is the development plan for the Water Extraction Area co-created by citizens and public officials. Another positive example of the potential values of participatory approaches in urban planning was the development of a major new residential area in the Vathorst neighborhood.

\subsection{Active Citizenship}

While the above-mentioned practices were all initiated by the municipality, some initiatives were also taken by active citizens. From the 1990s, many groups of citizens have pursued a wide variety of objectives throughout Amersfoort, including green space and environmental causes. In 1995 many of these groups came together and formed an umbrella association called 'Cooperation of groups for a Liveable Amersfoort' (CLA) [48]. This local coalition now consists of 15 groups. According to a local citizen involved with CLA, they were originally widely perceived as a 'protest movement'.

Closely related to citizens' green vision for the Elisabeth area, a specific group of active citizens founded the Foundation Heiligenbergerbeekdal in 2003 [49]. This Foundation employed activities towards a telos of improving the ecological and recreational opportunities in the Heiligenbergerbeekdal. In response to the plans of many local political parties to develop the Elisabeth site for housing, the Foundation developed an alternative, green vision for the entire area. In this vision, extensive recreation is combined with the development of an ecological corridor that leads from the green outskirts of Amersfoort up to the city center. Ecologically, this vision had a strong focus on biodiversity and connectivity, indicating wet nature areas close to the stream and drier parts in the areas of somewhat higher altitude. The vision also excludes paved infrastructure and only allows extensive sports facilities [49]. Foundation Heiligenbergerbeekdal immediately started to mobilize support for their vision and lobbied local politicians to promote it. They also joined CLA.

\subsection{Co-creations Between Municipality and Active Citizens}

In time, some of the people involved in CLA became frustrated because lobbying and protesting rarely achieved their objectives. In 2011, a number of CLA members set up The New Collaboration (TNC), a platform to develop better forms of collaboration between citizens and the municipality of Amersfoort [50]. TNC framed participation not in terms of active citizens joining up with the municipality, but rather as 'opportunities for the council to engage in participatory processes' and to 'join up with existing networks in the city'. To this end, TNC initiated brainstorming sessions with citizens, public officials, and politicians, organized a conference to discuss cooperation between citizens and public officials, and set up a 'city café' to facilitate a dialogue between citizens and municipal actors.

In developing a new practice to improve the relationship between local citizens and the municipal administration, TNC made a conscious decision to build on experiences of earlier practices. Highlighting previous successes in participatory governance, TNC actively promoted a discourse of true co-creation between the municipal authority and residents. They combined elements from earlier practices that link formal procedures and government resources with knowledge and active input by citizens. TNC also looked for new elements by inviting external experts and working on a vision with citizens and public officials. In all their activities, TNC explicitly tried to change the roles of actors as well as the dominant rules of the game: more collaboration between citizens and municipal actors and a sharing of responsibility and power through the building of trust between actors.

\subsection{Co-Creation of the Elisabeth Site}

In the period from 2004 to 2010, with the relocation of the hospital still many years away, no political decisions about the Elisabeth site were made. Despite lobbying by the Heiligenbergerbeekdal Foundation and growing support for their vision among the public, the local governing coalition in the municipal council and most other political parties still officially backed the development of the 
Elisabeth site for housing. There was one exception to this: the local liberal democrats (D66) had made the green development of the Elisabeth site one of the main promises in their electoral campaign in 2010. In 2012, the local governing coalition collapsed, and D66 became a member of the new local governing coalition. After negations between the involved political parties, this green vision was included in the new coalition agreement. While there is no uniform vision among respondents about what would have happened with the Elisabeth site, if these political changes wouldn't have occurred, they agree that the role of D66 was important in shaping the process. Some respondents suggested that the economic crisis and associated decreasing demand for housing might also have played a role.

As a majority of the municipal council now formally supported the Foundations' green vision, the executive councilor for spatial development (also a member of D66) started work on a new plan. At this time, TNC had just organized a well-attended conference about 'cooperation' and was actively promoting its discourse on co-creation between public officials and citizens. Inspired by TNC, the councilor proposed setting up an interactive process to develop the Elisabeth site 'together with citizens.' TNC's 'co-creation' discourse had been taken up and linked to a specific area: the redevelopment of the Elisabeth site.

When the decision was made to redevelop the Elisabeth site in this way, the executive councilor for spatial development contacted the chairman of TNC to set up an interactive process. In line with the ideas of TNC, Core group Elisabeth Green (CEG) was established to manage this process. CEG consisted of two public officials and eight citizens, including representatives from TNC, CLA and the Heiligenbergerbeekdal Foundation. Respondents describe the process to come to this group in different ways, varying from 'started somewhere behind the scenes' (a public official) to 'everyone could have been a member' (TNC-member). Formed in March 2013, CEG was formally in charge of the process of preparing a development plan and management plan for the Elisabeth site. Although the municipality set a limited number of tasks for CEG, including transforming the site into a 'largely green' area, the CEG was given the lead role in drawing up a new plan for the area, with an overall budget of $€ 1.5$ million for the development and management of the park.

Based on the TNC vision, CEG chose to focus on co-creation involving citizens and municipal officials. In 2013 they organized several meetings in which citizens made around 200 suggestions for the redevelopment of the area. Supporting working groups involving about 30 citizens and representatives of NGOs worked with CEG on a redevelopment plan for the area and an accompanying management plan. The process included a regular feedback loop with the relevant municipal departments, and the municipality council debated the subject on several occasions. The public was kept up to date and invited to comment via an online platform. While most sources are very positive about this involvement of citizens, one particular respondent was rather critical of this. She explained that it's 'mostly the same people' that also show up elsewhere. For her, these 'usual suspects' are not necessarily representative of the whole population of Amersfoort.

In the CEG, two distinct discourses became dominant: one on governance and one on content. The governance discourse focused on co-creation and collaboration between citizens and municipalities authorities. Resources from both citizens and municipality were mobilized to prepare the spatial plan and organize the process to implement it. The local networks of the citizens involved in CEG were crucial in strengthening links with local residents and mobilizing ecological knowledge, knowledge about the local cultural history, and other innovative ideas. The public officials in CEG concerned themselves with the relevant policy procedures and technical details, including the financial arrangements. This discourse on the process was largely influenced by TNC and supported by the citizens and municipal officials involved in the process.

While many participants in CEG focused on shaping the co-creation process, those involved in CEG and the supporting groups on behalf of the Heiligenbergerbeekdal Foundation were able to steer the content of the redevelopment plans towards a focus on greening the area. Members of this foundation provided important ecological knowledge in the development of the plans, which provided an important basis for decision making. A CEG respondent claimed that the final vision formulated by 
CEG could be traced back 'for about $90 \%$ ' to the original vision for a green space that the foundation had formulated in 2003. CEG's spatial vision explicitly aims to enlarge biodiversity and specific natural values, improving the (ecological) connectivity of the Heiligenbergerbeekdal, and promoting the (recreational) experience. More in detail, the plan promotes a 'park forest' with space for the stream to meander, marshes, carr forests, tree meadows, and dry woods. It includes a few paths for walking, equipment for kids to play, and an area where dogs are allowed to roam freely. This vision combines a strong focus on ecology with extensive forms of recreation, proposing to strengthen the environmental and historical structure of the landscape through rewilding, including small wetlands.

In December 2013, the municipal council almost unanimously approved the final development and management plan produced by CEG. Work on creating this park on the Elisabeth site began in 2018. The foundation's green discourse has become official policy through a process of co-creation as advocated by TNC. Both discourses in CEG were aligned towards the same telos (end-goal) of developing a green Elisabeth Park 'together with the city.'

\subsection{Transformation and Legacy}

The co-creation and subsequent political formalization of the plan by the municipal council can be considered the result of a collaboration between active citizens and innovative political parties and public officials. While this process was considered a success by most, if not all, stakeholders, developments after 2014 suggest that this success has also contributed to long-term changes in planning and management practices towards co-creation and co-management.

While CEG's work on the development and management plans has finished, and the group was dissolved in 2014, many citizens have expressed a desire to be involved in the management of the park. Residents are converting the only remaining building, a monumental boiler house, into a 'Park House,' which will contain a range of facilities, including a meeting room, a café, childcare facilities, and studios for local artists [51]. In addition, some residents have established a new foundation called the Elisabeth Green Foundation and have signed a formal cooperation agreement with the municipality for the management of the area [52]. At the time of writing (2019), citizens are organizing monthly working days in the area, which is still largely under development. This ongoing involvement of local residents is currently shifting the governance from co-creation towards co-management of the area.

The perceived success of this co-creation practice is having an influence on other practices in Amersfoort as well. Considering their activities a success due to a 'change in culture', TNC went into 'sleep mode' at the end of 2014 [50]. However, several people continued working to promote active citizenship and co-governance in Amersfoort, for example, through the establishment of an online platform. In addition, in 2014, the municipality appointed an 'administrative innovation' alderman, a rather unique position aiming to promote co-creation and collaboration officially. Furthermore, in 2014-2015, a green spatial vision for the city was interactively developed in a co-creation process. Also, citizens have been increasingly involved in the redevelopment of a road and have taken over a public building from the municipality. One of the citizens originally involved in CEG said, 'The legacy of CEG shows that you can achieve a lot with citizens ... The residents and the municipality both recognize that we really can do it together' (Figure 2). 


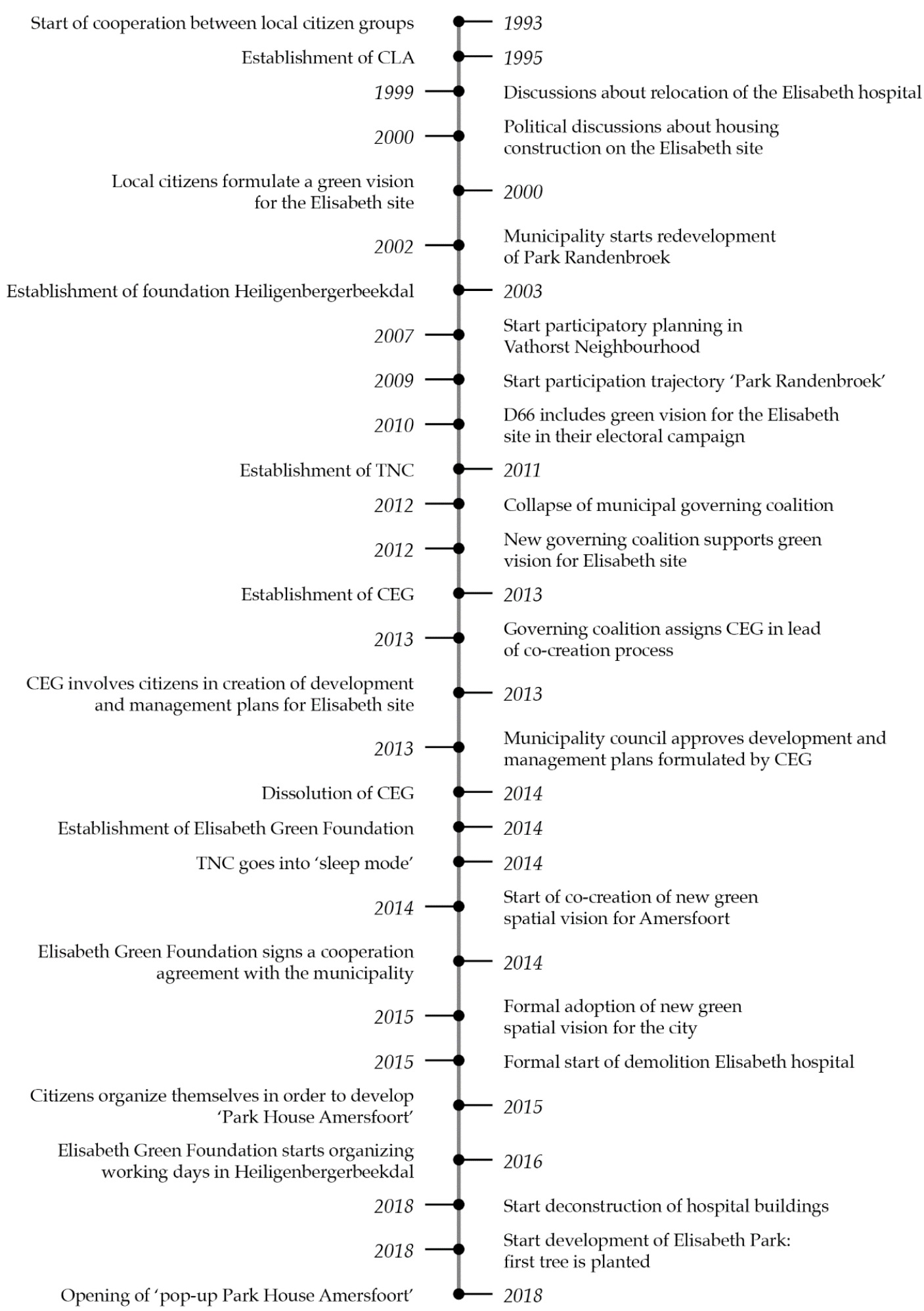

Figure 2. Timeline of important developments in our case study. Developments on the left were initiated by citizens or CEG, those on the right by municipality actors.

\section{Results Part 2: Understanding the Transformations in Local Practices}

As the focus of this paper is on understanding transformations in the relation between the state and civil society, we analyze these relations against the four elements of the governance practice we identified in the theory section: discourses, actors, resources, and rules. 


\subsection{Discourse}

As described above, the Heiligenbergerbeekdal Foundation was successful in promoting their discourse, raising it from the status of counter-discourse in 2003 to become the dominant discourse in 2014. Through their alliance with actors focusing on the collaboration discourse, the Foundation succeeded in steering the dominant policy discourses towards a green redevelopment of the Elisabeth site. This 'green' discourse excluded alternative options such as developing the area for sports or housing. Interestingly, we see that many subsequent developments were aligned with the original telos of the Foundation, indicating that their focus on cooperation still works towards the same end of a green Heiligenbergerbeekdal. It is important to recognize the constitutive role of materiality in the green discourse. The location of the Elisabeth site in the Heiligenbergerbeekdal makes it part of a green finger leading from the outskirts of Amersfoort into the city center, which is why a green ecological function was central to the Foundation's teleoaffectivity.

The 'collaboration' discourse promoted by TNC also traveled across practices before it eventually became dominant in discussions about the Elisabeth site. While advocated by TNC, it was inspired by previous experiences across several practices. Citizens' critiques on the process of redeveloping Park Randenbroek had put pressure on the municipal council's existing ways of working. However, the involvement of citizens in governance was not merely a way to implement green space policies more efficiently but became more of an objective in itself. The TNC discourse has been an influential factor in shifting the teleoaffectivity in municipal practices: 'the ideas [of TNC] have landed fairly well in Amersfoort' (respondent from TNC). Through its uptake in CEG and its persistence afterward, the collaboration discourse has now become embedded in a number of recently emerged practices.

\subsection{Actors}

In Amersfoort, new actors became involved in a variety of local governance practices. This was the case in the practices concerning the Water Extraction Area, Vathorst, TNC, CEG, Elisabeth Green Foundation, and the green spatial vision. Organized citizens have become actively involved in the creation and implementation of policy, while public officials have taken on a more facilitating role. The emergence of these new actor constellations has been linked to TNC's 'collaboration' discourse. Their role as a catalyzer is widely recognized-TNC's vision and activities played an important role in bringing the municipality and citizens together and shaping daily collaboration activities: 'that's exactly what we want ... to make that connection again' (TNC-member). Notwithstanding these forms of collaboration, there are some critiques on involved citizens mostly being 'the usual suspects'.

The situated agency of people in key positions played an important role in shaping the practice around CEG. The public and official support for the 'collaboration' discourse and the council's decision to green the Elisabeth site provided a political window of opportunity for the executive councilor for spatial development to start the process. The chairman of CLA, also one of the initiators of TNC and a member of D66, was invited by the councilor to establish CEG and had an important role in shaping the early process, as he was given a lot of freedom to do so. Most people in CEG attributed more value to the governance process than to its substance; therefore, the representative of the Heiligenbergerbeekdal Foundation in CEG could promote their vision for the area.

\subsection{Resources}

Finance still mostly comes from municipal sources: the municipal council allocated $€ 1.5$ million for the redevelopment of the Elisabeth site and also purchased the 8 ha of land. However, the citizens' initiative to purchase the boiler house shows that citizens do contribute financial resources as well. When we look at the role of materiality as a resource, the biotic and abiotic conditions of the Elisabeth-area were important in the creation of the development and management plans, where 'wet' and 'dry' parts were planned to fit these conditions. Some of the existing infrastructure (paths and roads) was incorporated for use in these plans, as well. 
When we look at attributes and competencies, an ongoing shift is already visible. First, the citizens in CEG increasingly provided not only knowledge and expertise about ecology and cultural history, but also cultural and social capital related to organizational capacities and mobilizing capacities related to local residents. The people in TNC contributed expertise concerning the organization of activities, while representatives from FH and other local NGOs contributed important ecological and environmental knowledge. In addition, individual residents also provided input to the development and management plans, contributing over 200 ideas, many of which were incorporated into the development of the Elisabeth site. Meanwhile, public officials were important in ensuring the process met the requirements of official procedures but also contributed to the substance of the plans.

\subsection{Rules of the Game}

The formal logic of the municipality and a more informal approach of citizens did not always align in practice. Our study shows how regulatory elements, such as the formalization of development plans by the council, are deeply institutionalized in municipal practices. Here, CEG was forced to follow established rules. Consequently, regulatory elements continued to exert a strong hold over CEG's activities. CEG's progress was regularly discussed during official council meetings and subjected to official financial and legal scrutiny; public officials had to account for certain proceedings and/or write parts of reports. Respondents claimed that not all public officials were willing to derive from existing ways of working: 'at the moment that you've sufficiently discussed the framework with the municipality, then the municipality should eventually approve the plan without a doubt if it fits the framework. But then, you should not at the last moment say 'a bit of this or that'. Then you cut through the process and end up on the old positions' (CEG-member).

New rules for collaboration needed to be developed within the existing regulatory framework, and the citizens in CEG played an important part in this. In addition, the support for co-creation also enabled the municipal officials to 'bend' some rules and directives that were originally set by the municipality. While some rules persisted, others changed, or flexible interpretations were allowed. For example, due to time pressure, a formally obligatory round of consultation was skipped, it is argued that consultation had already taken place at other moments. Content-wise, the original directive for the Elisabeth-location prescribed three small areas where dogs could roam freely. During discussions, CEG discovered that citizens preferred one large area instead. This change from the official directives was accepted by the municipality.

\section{Discussion}

\subsection{The Transformative Potential of Active Citizenship}

This paper investigates the role of active citizenship in the transformation of governance practices. As we have shown, the discourses promoted and resources contributed by citizens have played an important role in (the process of) redesigning the Elisabeth site. We observed a transformation in the relationship between citizens and authorities in the realization of green space and its management. In this way, citizens have promoted the benefits offered by urban green space as well as 'new ways of working' in local governance. While the transformation of the built-up area into green space is nothing new in Western cities, the co-creative nature of the process on this spatial scale and with this many people involved is unique in the Netherlands [cf. 9]. More importantly, the co-creation practices, in our case, have inspired others and promoted co-creation in green and non-green domains.

Despite many critical perspectives in the literature, such as $[18,26]$, our analysis does highlight the role of citizens as situated agents capable of transforming many elements across governance practices. We show a change in terms of the involved actors and the discourses promoted by these actors, but also in resources (forms of capital contributed by citizens) and rules (skipping of formal procedures, the involvement of CEG in official meetings of authorities). The exchange of elements between practices 
plays a key role in both the substance and the process of these transformations. Social connectivity between practices is thus important for the transformative potential of active citizenship $[8,23,29]$.

\subsection{Change and Stability}

Our analysis shows that several elements from previous practices played an important role in this transformation towards co-creative practices in Amersfoort. Over the years, authorities and active citizens have developed several new forms of co-creation by exchanging elements between practices, such as actors, resources, discourses, and rules. These transformations have taken place through daily collaboration, with the municipality supporting the upscaling and institutionalization of active citizenship [the importance of such support is also highlighted by [28,29,53,54].

This process of change was a gradual and path-dependent one in which actors consciously promoted certain elements and also adapted to changes, such as elections and the economic crisis. Like Shove, Pantzar, and Watson [34], we highlight how experiences in previous practices have consequences for the development and shaping of new practices. Our case illustrates that such experiences can be both positive and negative: successful co-creation in certain practices inspired a similar process in others. However, the municipalities' negative experiences with angry citizens and frustrations among citizens that protest did not lead to the accomplishment of their objectives also contributed to a search for collaboration.

While our analysis highlights changes for almost all elements, it also shows that the process of redeveloping the Elisabeth site is connected to existing institutions (rules, resources, actors). In this context, it is also important to look at what elements did not change. Across practices, authorities retain an important role in setting frameworks and objectives, formalizing spatial plans, issuing permits, and maintaining regulations. In this, we see that legal, regulatory frameworks for formalizing decision making (such as the role of the municipal council in taking formal decisions) remain in place. The observed change has thus mostly taken shape within the formal boundaries of the existing democratic system, but within these boundaries, there was flexibility in creating and implementing spatial plans.

\subsection{Conflict and Collaboration}

An important conclusion about the transformations in Amersfoort is that they have taken place in the context of both contestation and collaboration. The contestation phase of citizen involvement may have provided a constituency, legitimacy and knowledge, and thus, power to involved citizen groups. It was, however, only through collaboration that discourses on greening the area became part of newly emerging practices of co-creation. While conflicts can have a constitutive role in societal transformations [55], our study shows that a shift in citizens' activities from protest towards collaboration was a key turning point towards transformation. While Isin [24] might still label the citizens in our case study as 'activist' as they desired fundamental change in governance, citizens started to employ different means towards this end.

Collaboration with authorities can be beneficial to the success of active citizens in reaching their objectives [23,28,29,53]. In agreeance with the work of Borgström [54], we, therefore, wish to emphasize that an important part of citizens' transformative capacity is linked to an enabling environment for citizen engagement in new forms of governance as well as to authorities' openness for collaboration. In CEG, we have seen how such cooperation provided citizens with the situated agency to influence the outcome of the process and the way in which it was given shape. Like Colding et al. [15], we observe that it may be beneficial for active citizens to align with existing legal frameworks in order to be influential, even if it requires them to play by the formal rules of the game. Yet, as this requires citizens to 'play by the rules', it does somewhat confirm the trade-off between the independence of active citizens and their influence in the public domain [20,29]. 


\section{Conclusions}

Somewhat paradoxically, active citizenship, and new forms of governance often require legitimization and formalization by the representative democratic system that citizens aim to transform see also [17]. That is why strongly institutionalized elements often retain an important role in 'new' practices, steering the activities that these citizens employ. The shift in citizens' activities from protest towards collaboration was a key turning point in our case study. By aligning with existing rules and resources, citizens can become powerful situated agents that transform governance institutions. Although our research may suggest a trade-off between the autonomy and power of citizens involved in governance practices, it especially shows how, in certain circumstances, citizens can realize significant transformations in governance.

Our analysis illustrates that elements from certain practices can travel to other practices if teleoaffectivities are sufficiently aligned. In this sense, the success of practices that involve active citizens in governance can make way for more inclusion of citizens in other practices. This change across practices can eventually transform local governance systems and produce substantial changes in the public domain. When we talk about transformations, it is thus important not only to focus on specific practices but also to consider the interactions and exchange of elements between various practices $[8,29]$. In this, a challenge for citizens and policymakers that strive for urban greening or democratic renewal will be to create and maintain effective partnerships in the city [11].

Author Contributions: This research was developed and set-out by A.A.E.B., R.I.v.D. and T.J.M.M., who have collected and analyzed the research data in the case study together with J.L.M.D. The writing process was led and supervised by T.J.M.M. B.J.M.A. has specifically contributed to the theory and discussion sections, while B.H.M.E. and A.A.E.B. had an important role in co-developing the scope and subject of the article. All authors contributed to the analytical part of this paper, led by T.J.M.M. and co-edited by A.A.E.B. Revisions to the original article after peer review were made by T.J.M.M.

Funding: This research has been funded by the PBL Netherlands Environmental Assessment Agency.

Acknowledgments: The authors would like to thank Derek Middleton for English language editing and WOT Natuur \& Milieu for their provision of these language editing services. We also wish to express our gratitude to the two anonymous peer reviewers, whose critical reflection has helped us to improve this article.

Conflicts of Interest: The authors declare no conflict of interest.

\section{Abbreviations}

The following abbreviations are used in this manuscript

- $\quad$ CLA = Cooperation of groups for a Liveable Amersfoort, a collective organization of local NGOs (Dutch: Samenwerkende Groeperingen Leefbaar Amersfoort).

- $\quad$ TNC $=$ 'The New Collaboration,' a citizens' initiative to promote collaboration between municipal governments and citizens (Dutch: Het Nieuwe Samenwerken).

- D66 = Democrats 66, a liberal democratic political party (Dutch: Democraten 66).

- $\mathrm{CEG}=$ Core group Elisabeth Green, the group in charge of developing the vision for the Elisabeth site (Dutch: Kerngroep Elisabeth Groen).

\section{References}

1. Moro, G. Citizens in Europe: Civic Activism and the Community Democratic Experiment; Springer: New York, NY, USA, 2012; pp. 1-210.

2. Van Dam, R.; Duineveld, M.; During, R. Delineating active citizenship: The subjectification of citizens' initiatives. J. Environ. Policy Plan. 2015, 17, 163-179. [CrossRef]

3. Hajer, M.; Nilsson, M.; Raworth, K.; Bakker, P.; Berkhout, F.; de Boer, Y.; Rockström, J.; Ludwig, K.; Kok, M. Beyond cockpit-ism: Four insights to enhance the transformative potential of the sustainable development goals. Sustainability 2015, 7, 1651-1660. [CrossRef]

4. Scientific Council for Government Policy. Confidence in Citizens; Scientific Council for Government Policy: The Hague, The Netherlands, 2013; p. 27.

5. Rosol, M. Public participation in post-fordist urban green space governance: The case of community gardens in Berlin. Int. J. Urban Reg. Res. 2010, 34, 548-563. [CrossRef] [PubMed] 
6. Mattijssen, T.J.M.; Van der Jagt, A.; Buijs, A.E.; Elands, B.H.M.; Erlwein, S.; Lafortezza, R. The long-term prospects of citizens managing urban green space: From place making to place keeping? Urban For. Urban Green. 2017, 26, 78-84. [CrossRef]

7. Perkins, H.A. Green spaces of self-interest within shared urban governance. Geogr. Compass 2010, 4, $255-268$. [CrossRef]

8. Buijs, A.E.; Hansen, R.; Van der Jagt, S.; Ambrose-Oji, B.; Elands, B.H.M.; Rall, E.; Mattijssen, T.J.M.; Pauleit, S.; Runhaar, H.A.C.; Stahl Olafsson, A.; et al. Mosaic governance for urban green infrastructure: Upscaling active citizenship from a local government perspective. Urban For. Urban Green. 2019, 40, 53-62. [CrossRef]

9. Mattijssen, T.J.M.; Buijs, A.E.; Elands, B.H.M.; Arts, B. The green and self in green self-governance: A study of 264 green citizen initiatives. J. Environ. Policy Plan. 2018, 20, 96-113. [CrossRef]

10. Buijs, A.; Mattijssen, T.J.M.; Van der Jagt, A.P.N.; Ambrose-Oji, B.; Andersson, E.; Elands, B.H.; Møller, M.S. Active citizenship and the resilience of urban green: Fostering the diversity and dynamics of citizen contributions through mosaic governance. Curr. Opin. Environ. Sustain. 2016, 22, 1-6. [CrossRef]

11. Krasny, M.E.; Tidball, K.G. Civic ecology: A pathway for earth stewardship in cities. Front. Ecol. Environ. 2012, 10, 267-273. [CrossRef]

12. Spijker, S.N.; Parra, C. Knitting green spaces with the threads of social innovation in groningen and london. J. Environ. Plan. Manag. 2017, 61, 1011-1032. [CrossRef]

13. Mattijssen, T.; Buijs, A.; Elands, B. The benefits of self-governance for nature conservation: A study on active citizenship in the netherlands. J. Nat. Conserv. 2018, 43, 19-26. [CrossRef]

14. Krasny, M.E.; Russ, A.; Tidball, K.G.; Elmqvist, T. Civic ecology practices: Participatory approaches to generating and measuring ecosystem services in cities. Ecosyst. Serv. 2014, 7, 177-186. [CrossRef]

15. Colding, J.; Barthel, S.; Bendt, P.; Snep, R.; Van der Knaap, W.; Ernstson, H. Urban green commons: Insights on urban common property systems. Glob. Environ. Chang. 2013, 23, 1039-1051. [CrossRef]

16. Wolfram, M.; Frantzeskaki, N. Cities and systemic change for sustainability: Prevailing epistemologies and an emerging research agenda. Sustainability 2016, 8, 144. [CrossRef]

17. Mattijssen, T.J.M.; Behagel, J.H.; Buijs, A.E. How democratic innovations realise democratic goods. Two case studies of area committees in the netherlands. J. Environ. Plan. Manag. 2015, 58, 997-1014. [CrossRef]

18. Swyngedouw, E. Governance innovation and the citizen: The janus face of governance-beyond-the-state. Urban Stud. 2005, 42, 1991-2006. [CrossRef]

19. Ostrom, E. Beyond markets and states: Polycentric governance of complex economic systems. Am. Econ. Rev. 2010, 100, 641-672. [CrossRef]

20. Frantzeskaki, N.; Dumitru, A.; Anguelovski, I.; Avelino, F.; Bach, M.; Best, B.; Binder, C.; Barnes, J.; Carrus, G.; Egermann, M.; et al. Elucidating the changing roles of civil society in urban sustainability transitions. Curr. Opin. Environ. Sustain. 2016, 22, 41-50. [CrossRef]

21. Fisher, D.; Svendsen, E.; Connolly, J. Urban Environmental Stewardship and Civic Engagement: How Planting Trees Strengthens the Roots of Democracy; Routledge: Abingdon, UK, 2015.

22. Wagenaar, H.; Healey, P.; Laino, G.; Vigar, G.; Riutort Isern, S.; Honeck, T.; Beunderman, J.; Van der Heijden, J. The transformative potential of civic enterprise. Plan. Theory Pract. 2015, 16, 557-585. [CrossRef]

23. Blühdorn, I.; Deflorian, M. The collaborative management of sustained unsustainability: On the performance of participatory forms of environmental governance. Sustainability 2019, 11, 1189. [CrossRef]

24. Isin, E.F. Citizenship in flux: The figure of the activist citizen. Subjectivity 2009, 29, S1. [CrossRef]

25. Enqvist, J. Stewardship in an Urban World: Civic Engagement and Human-Nature Relations in the Anthropocene; Stockholm University: Stockholm, Sweden, 2017.

26. Aiken, G.T. The politics of community: Togetherness, transition and post-politics. Environ. Plan. A 2017, 49, 2383-2401. [CrossRef]

27. García, M. Citizenship practices and urban governance in european cities. Urban Stud. 2006, 43, 745-765. [CrossRef]

28. De Wilde, M.; Hurenkamp, M.; Tonkens, E. Flexible relations, frail contacts and failing demands: How community groups and local institutions interact in local governance in the netherlands. Urban Stud. 2014, 51, 3365-3382. [CrossRef]

29. Franklin, A.; Marsden, T. (Dis)connected communities and sustainable place-making. Local Environ. 2015, 20, 940-956. [CrossRef] 
30. Leontidou, L. Urban social movements in 'weak' civil societies: The right to the city and cosmopolitan activism in southern europe. Urban Stud. 2010, 47, 1179-1203. [CrossRef]

31. Arts, B.J.M.; Behagel, J.H.; Bommel, S.V.; Koning, J.D.; Turnhout, E. Prelude to practice: Introducing a practice based approach to forest and nature governance. In Forest and Nature Governance. A Practice Based Approach; Arts, B.J.M., Behagel, J.H., Bommel, S.V., Koning, J.D., Turnhout, E., Eds.; Springer: Dordrecht, The Netherlands, 2013.

32. Schatzki, T. A primer on practices. In Practice-Based Education. Perspectives and Strategies; Higgs, J., Barnett, R., Billett, S., Hutchings, M., Trede, F., Eds.; Sense Publishers: Rotterdam, The Netherlands, 2012; pp. $13-27$.

33. Reckwitz, A. Towards a theory of social practices. A development in culturalist theorizing. Eur. J. Soc. Theory 2002, 5, 243-263. [CrossRef]

34. Shove, E.; Pantzar, M.; Watson, M. The Dynamics of Social Practice: Everyday Life and How It Changes; Sage Publications: London, UK, 2012.

35. Reckwitz, A. Practices and their affects. In The Nexus of Practices: Connections, Constellations, Practitioners; Taylor and Francis: London, UK, 2016; pp. 114-125.

36. Schatzki, T. The Timespace of Human Activity: On Performance, Society, and History as Indeterminate Teleological Events; Lexington Books: Lanham, MD, USA, 2010; p. 278.

37. Shove, E.; Spurling, N. Sustainable Practices-Social Theory and Climate Change; Routledge: London, UK; New York, NY, USA, 2013; Volume 95.

38. Feldman, M.S.; Orlikowski, W.J. Theorizing practice and practicing theory. Organ. Sci. 2011, 22, 1240-1253. [CrossRef]

39. Barad, K. Posthumanist performativity: Toward an understanding of how matter comes to matter. Signs 2003, 28, 801-831. [CrossRef]

40. Bevir, M. New Labour: A Critique; Routledge: London, UK, 2005.

41. Van Tatenhove, J.; Arts, B.; Leroy, P. Political Modernisation and the Environment. The Renewal of Environmental Policy Arrangements; Kluwer Academic Publishers: Dordrecht, The Netherlands, 2000.

42. Liefferink, D. The dynamics of policy arrangements: Turning round the tetrahedron. In Institutional Dynamics in Environmental Governance; Arts, B., Leroy, P., Eds.; Springer: Dordrecht, The Netherlands, 2006; pp. 45-68.

43. Giddens, A. The Constitution of Society: Outline of the Theory of Structuration; Polity Press: Cambridge, UK, 1984.

44. Hargreaves, T.; Longhurst, N.; Seyfang, G. Up, down, round and round: Connecting regimes and practices in innovation for sustainability. Environ. Plan. A 2013, 45, 402-420. [CrossRef]

45. Yin, R.K. Case Study Research. Design and Methods; Sage Publications: Thousand Oaks, CA, USA; London, UK; New Delhi, India, 1994.

46. Flyvbjerg, B. Five misunderstandings about case-study research. Qual. Inq. 2006, 12, 219-245. [CrossRef]

47. Yin, R.K. Applications of Case Study Research, 3 ed.; Sage Publications, Inc.: London, UK, 2012.

48. SGLA. Samenwerkende Groeperingen Leefbaar Amersfoort. Available online: www.sgla.nl (accessed on 26 June 2019).

49. Stichting Heiligenbergerbeekdal. Het Beekdal. Available online: www.hetbeekdal.nl (accessed on 7 October 2019).

50. Het Nieuwe Samenwerken. Available online: www.hetnieuwesamenwerken.net (accessed on 7 November 2019).

51. Parkhuis Amersfoort. Available online: http://www.parkhuisamersfoort.nl/ (accessed on 7 November 2019).

52. Stichting Elisabeth Groen. Elisabeth Groen. Available online: https://www.elisabethgroen.nl/ (accessed on 26 September 2019).

53. Aalbers, C.B.E.M.; Sehested, K. Critical upscaling. How citizens' initiatives can contribute to a transition in governance and quality of urban greenspace. Urban For. Urban Green. 2018, 29, 261-275. [CrossRef]

54. Borgström, S. Balancing diversity and connectivity in multi-level governance settings for urban transformative capacity. Ambio 2019, 48, 463-477. [CrossRef] [PubMed]

55. Kenis, A.; Bono, F.; Mathijs, E. Unravelling the (post-)political in transition management: Interrogating pathways towards sustainable change. J. Environ. Policy Plan. 2016, 18, 568-584. [CrossRef]

(C) 2019 by the authors. Licensee MDPI, Basel, Switzerland. This article is an open access article distributed under the terms and conditions of the Creative Commons Attribution (CC BY) license (http://creativecommons.org/licenses/by/4.0/). 